\title{
Morphology, germination, and geographic distribution of Pentaclethra macroloba (Fabaceae): a hyperdominant Amazonian tree
}

\author{
Adelson Rocha Dantas ${ }^{1 *}$, Marcelino Carneiro Guedes ${ }^{2}$, Caroline da Cruz Vasconcelos ${ }^{3}$, \\ Jaynna Gonar Lôbo Isacksson ${ }^{4}$, Dayane Nathália Barbosa Pastana ${ }^{5}$, Ana Cláudia Lira-Guedes ${ }^{2}$ \\ \& Maria Teresa Fernandez Piedade ${ }^{1}$ \\ 1. Programa de Pós-graduação em Ecologia, Instituto Nacional de Pesquisas da Amazônia, Manaus, Brasil; \\ adelson.dantas@yahoo.com.br, maua.manaus@gmail.com \\ 2. Departamento de Recursos Florestais, Empresa Brasileira de Pesquisa Agropecuária, Macapá, Brasil; \\ marcelino.guedes@embrapa.br, ana-lira.guedes@embrapa.br \\ 3. Programa de Pós-graduação em Botânica, Instituto Nacional de Pesquisas da Amazônia, Manaus, Brasil; \\ cc_vasconcelos@hotmail.com \\ 4. Grupo de Pesquisa em Ecologia Florestal, Instituto de Desenvolvimento Sustentável Mamirauá, Tefé, Brasil; \\ jaynnagonar@hotmail.com \\ 5. Programa de Pós-graduação em Engenharia Florestal, Universidade Federal de Lavras, Lavras, Brasil; \\ dayanepastana@gmail.com \\ * Correspondence
}

Received 10-VIII-2020. Corrected 04-XI-2020. Accepted 13-XI-2020.

\begin{abstract}
Introduction: Pentaclethra macroloba is a hyperdominant tree in the Amazon estuary of great socioeconomic importance for the region because the oil from its seeds is a powerful herbal medicine. Objective: We aimed to characterize the morphological structure, the morphological adaptations in response to the daily flooding of the Amazon estuary and the biogeographic area of P. macroloba. Methods: Detailed description of the external morphology, from germination to the adult tree, was obtained from individuals located in floodplain forest, Northeast Amazonia. The occupation area and the geographical extension of $P$. macroloba were determined from point of geographical coordinates of botanical samples deposited in the digital collections of Mobot and SpeciesLink. Results: Adult individuals have adapted structures in response to daily flooding, such as: adventitious roots to increase respiratory efficiency and lenticels in the trunk, serving as a connection point for oxygen transport between the root and the aerial part. Dried fruit favours the activation of the explosive dehiscence mechanism, allowing the seed to be expelled long distance. Deltoid shape of the seed allows water fluctuation and more efficient dispersal. Seedling is phanerocotylar hypogeal and with one pair of reserve cotyledons that provide the seedling an extra source of energy to escape the flood. Germination rate was $78 \%$ and the speed was 0.2 seeds.day ${ }^{-1}$. Circular buffer method revealed the presence of 123 subpopulations of P. macroloba distributed in a radius of $5699943 \mathrm{~km}^{2}$ across the Neotropical region. Conclusions: Much of the morphological structures of $P$. macroloba are adaptive and evolutionary responses to the periodically flooded environment of the Amazon estuary, showing that these environments select the trees, best adapted, to inhabit the flood. P. macroloba has a wide geographical area denotes the plasticity of adapting to different environments, which may justify its monodominance in some regions.
\end{abstract}

Key words: morphological adaptation; tidal flooding; Neotropical tree; adventitious roots; pracaxi oil; management, conservation.

Rocha Dantas, A., Carneiro Guedes, M., da Cruz Vasconcelos, C., Lôbo Isacksson, J.G., Barbosa Pastana, D.N., Lira-Guedes, A.C., \& Fernandez Piedade, M.T. (2021). Morphology, germination, and geographic distribution of Pentaclethra macroloba (Fabaceae): a hyperdominant Amazonian tree. Revista de Biología Tropical, 69(1), 181-196. DOI 10.15517/rbt.v69i1.43446 
Some tree species in the Amazon region have great dominance, occurring in a wide area, others have isolated populations and their distribution is restricted to a specific environment (ter Steege et al., 2013). The great challenge for many forest ecologists is to understand the mechanisms and strategies that trees develop over time to colonize the most varied environments in the Amazon rainforest.

In the Amazon floodplain, the periodically flooded environment can promote speciation and adaptation processes in the trees that inhabit this environment. Various adaptations in the external morphology of the plants are observed in response to the low availability of oxygen in the rhizosphere and the constant erosion of the soil, such as high density of lenticels in the trunk and the presence of roots and aerial structures: rhizophores, pneumatophores, haustoria and buttresses (Almeida, Amaral, \& Silva, 2004; Parolin, 2012).

In Central Amazonia, flooding in the forest can last up to 243 days and reach a height of up to $6 \mathrm{~m}$ on the tree trunk (Schöngart, Piedade, Ludwigshausen, Horna, \& Worbes, 2002). Trees respond to this long period of flooding reducing metabolic activity, which in many cases leads to leaf fall in the canopy (De Simone, Junk, \& Schmidt, 2003) and formation of annual rings on the trunk (Schöngart et al., 2004). However, in the Eastern Amazon, the knowledge of the morphological and ecophysiological adaptations of tree species that grow under the regime of daily flooding and low amplitude of the Amazon estuary (Junk et al., 2011) is still quite modest.

The floodplains of the Amazon estuary have several endemic and dominant species as Pentaclethra macroloba. Species of the Fabaceae family, popularly known by name "pracaxi” (Dantas, Marangon, Guedes, Feliciano, \& Lira-Guedes, 2017). This species is hyperdominant Amazon (Ter Steege et al., 2013) and large occurrence in Amazon estuary (Carim, Wittmann, Piedade, Guimarães, \& Tostes, 2016). Among the three populations of $P$. macroloba in Neotropical America, little is known about the natural history of the population that lives in the Amazon Basin (Hartshorn, 1983).

P. macroloba is an important non-timber species in the local socioeconomic, source of income for several riverside Amazon, due to its multiple uses. The bark of the tree trunk has triterpenoid saponins that have anti-haemorrhagic action against the venom of snakes of the Bothrops genus (Silva et al., 2007). The oil extracted from the seeds is a powerful natural medicine, which is very common riverside Amazon people to use this oil to treat muscle pain and inflammation. The oil has a high concentration of fatty acids that moisturize the skin (Costa et al., 2014), which is highly requested by the cosmetics industry as raw material.

Despite the great arboreal biodiversity of the Amazon, information on the basic morphology of plant species is still lacking, difficult to understand the evolutionary adaptations of trees to the environment. In addition, studies of plant morphology are important to ensure the correct identification of trees and natural regeneration (Melo, Mendonça, \& Mendes, 2004), indispensable requirement in biodiversity inventory.

Dispersion patterns of the trees has great contribution to the diversification of the Amazon rainforest (Gentry, 1981). The biogeographic patterns of trees are the result, in many cases, of limited dispersion (Wiens, 2011) and reveal characteristics of its ecology and evolutionary biology (Gaston \& Fuller, 2009), important knowledge for conservation strategies of species that have economic potential, such as P. macroloba.

In this study, we evaluated the morphological adaptations of $P$. macroloba in response to the daily flooding of the Amazon estuary. We provide a detailed description of the external morphology of $P$. macroloba and evaluate its biogeographic area to assist in the management and conservation of this species.

\section{MATERIALS AND METHODS}

Study area: Botanical material was collected from individuals located in two 
floodplain areas: Mazagão Experimental Field (CEM) and Fazendinha Environmental Protection Area (APA da Fazendinha hereafter), State of Amapá, Brazil. CEM belongs to the Brazilian Agricultural Research Corporation, located in the city of Mazagão $\left(00^{\circ} 02^{\prime} 33^{\prime \prime} \mathrm{S}\right.$ \& $\left.51^{\circ} 15^{\prime} 24^{\prime \prime} \mathrm{W}\right)$, it has 55.95 ha of floodplain forest and is bathed by the tributary of the Amazon River called "furo do Mazagão". The APA da Fazendinha is located in the city of Macapá $\left(00^{\circ} 03\right.$ '04.24” S \& 51 ${ }^{\circ} 07^{\prime} 42.72$ ' W), it has 13659 ha of floodplain forest and is directly bathed by the Amazon River.

The climatic system of the region is Am (Köppen classification), tropical rainy (Alvares, Stape, Sentelhas, Gonçalves, \& Sparovek, 2013), and in the state of Amapá, the rainy season begins in December, with the concentration of rainfall in the month of March where the peak of precipitation is above $60 \mathrm{~mm}$ until the month of August. The dry season starts in September when the monthly rainfall is below 60 mm (Vilhena, Silva, \& Freitas, 2018). The soils of the area are classified as typical Melanic Gleysols Ta Eutrophic, with predominance of silt. Both the sediment and the soil are formed by smectite, illite, kaolinite, goethite, anatase and quartz (Pinto, 2014).

The vegetation is classified as dense alluvial ombrophilous forest (IBGE, 2012), with predominance of species Mora paraensis, Astrocaryum murumuru, P. macroloba, Carapa guianensis and Virola surinamensis (Carim et al., 2016).

Data collection: Morphological description of the 34 adult trees (30 trees in APA and 4 trees in CEM) occurred in the field, observing their characteristics from the trunk base towards the top of the crown. After the description of the tree adults, fertile branches containing flowers, fruits and seeds were collected with the help of a pruning stick of $10 \mathrm{~m}$ and the usual tree climbing technique according to Laman (1995).

Branches were stored in moistened polyethylene bags and sent to the Embrapa Seed Laboratory, where the structures were measured and morphological description was conducted, through a specialized form with botanical terms. After the description, exsiccates were prepared for deposit in the Embrapa Herbarium Amazônia Oriental - IAN, Belém, Pará (registration numbers IAN192676 and IAN192677).

Morphological structures of the trunk, branches, leaves, flowers, fruits, seeds and seedlings were recorded using a Canon ${ }^{\circledR}$ camera (Model EOS Rebel T2i). Small structures were recorded using a Leica stereomicroscope (model EZ4D) with fixed camera.

The morphological stages of fruit and seed maturation were determined monitoring 30 individuals, during the period from April 2018 to March 2019 in the APA da Fazendinha. It was possible to observe the development of the first fruits, as well as to determine the maturation time and the morphological changes that occurred over time. The fruits that showed any significant change in shape or colour in the crown were collected, measured, and photographed. A chronological sequence of the maturation of fruits and seeds was built.

For the morphometric analysis, 54 fruits and 114 seeds were collected to obtain fresh mass $(\mathrm{g})$, length $(\mathrm{mm})$, width $(\mathrm{mm})$ and thickness $(\mathrm{mm})$. Fruits and seeds were weighed on analytical balance (Shimadzu ${ }^{\circledR}$ model AUW22OD, Japan), with accuracy of $0.001 \mathrm{~g}$. The measures of length, width and thickness were measured with a digital caliper (Carbografite ${ }^{\circledR}$ model 150 , accuracy of $0.01 \mathrm{~mm}$ ).

To evaluate the germination process and seedling phases, 60 seeds (4 replicates $\mathrm{x} 15$ seeds) were sown in plastic trays ( $45 \times 28 \times 7.5$ $\mathrm{cm})$, containing sand as substrate sterilized at $100{ }^{\circ} \mathrm{C}$ and vermiculite of medium particle size (1:1 ratio). The germination phases and seedling formation were monitored every two days in a greenhouse, for a period of six months.

The dispersal pattern of the species was analysed through the geographical coordinates of the botanical samples deposited in the digital repositories of the Missouri Botanical Garden (Tropicos, 2019) and SpeciesLink (CRIA, 2019). 
Data analysis: All descriptions of the morphological characteristics of $P$. macroloba followed a standardized form in botanical terms, based on botanical literature (Barroso, Morim, Pioxoto, \& Ichaso, 2004; Gonçalves \& Lorenzi, 2011; Harris \& Harris, 2001). Mean \pm standard deviation and coefficient of variation (CV) of the morphometric data were calculated. The morphometric relationships between fruits and seeds were evaluated using simple linear regression. The significance of the relationship was assessed by analysis of variance at $0.05 \%$ probability. The percentage of germinated seeds, average germination time and the germination speed were determined (Maguire, 1962). Germinated seed was considered when the cotyledons open emitting the epicotyl and the seedling phase begins with the expansion of the first pair of leaves (Camargo, Ferraz, Mesquita, Santos, \& Brum, 2008).

Geographic dispersal map of the species was prepared in the software QGIS 2.18. The extent of occurrence (EOO), area of occupation (AOO) and number of subpopulations (IUCN, 2017) of $P$. macroloba were determined using the statistical package ConR (Dauby, 2019). The number of subpopulations was estimated using the circular buffer method (Rivers, Bachman, Meagher, Lughadha, \& Brummitt, 2010).
All statistical analysis were performed using the R program (R core Team, 2019).

\section{RESULTS}

Description of adult trees in the field: $P$. macroloba (Fig. 1A) has an average height of $13 \mathrm{~m}$ (maximum $37 \mathrm{~m}$ ) and $26 \mathrm{~cm}$ of diameter (maximum $59 \mathrm{~cm}$ ). The base of the trunk (Fig. 1F) can be channelled or in buttresses, with the tree stem (Fig. 1B) straight or inclined and cylindrical shape. Rhytidome (outer bark) has a rough texture and with a mixture of green and grey colors (presence of lichen stains, Fig. 1D), with abundant elliptical and blackish green lenticels (Fig. 1C). The phloem (inner bark) is reddish and the sapwood is yellowish (Fig. 1E). The tree does not show exudate when the rhytidome is injured However, one day after, the tree exudes a colourless and viscous liquid (Fig. 1I). During the flood period of the Amazon estuary, P. macroloba produces a large number of adventitious roots (Fig. 1H). Individuals often show spread of branches at the base of the trunk (Fig. 1G).

The leaves $(21.3 \pm 4.7 \mathrm{~cm})$ are bipinnate (Fig. 2A), paripinnate, with alternate spiral phyllotaxy (Fig. 2C) and have 6-15 pairs of leaflets $(8.6 \pm 2.8 \mathrm{~cm})$. When new, the leaves
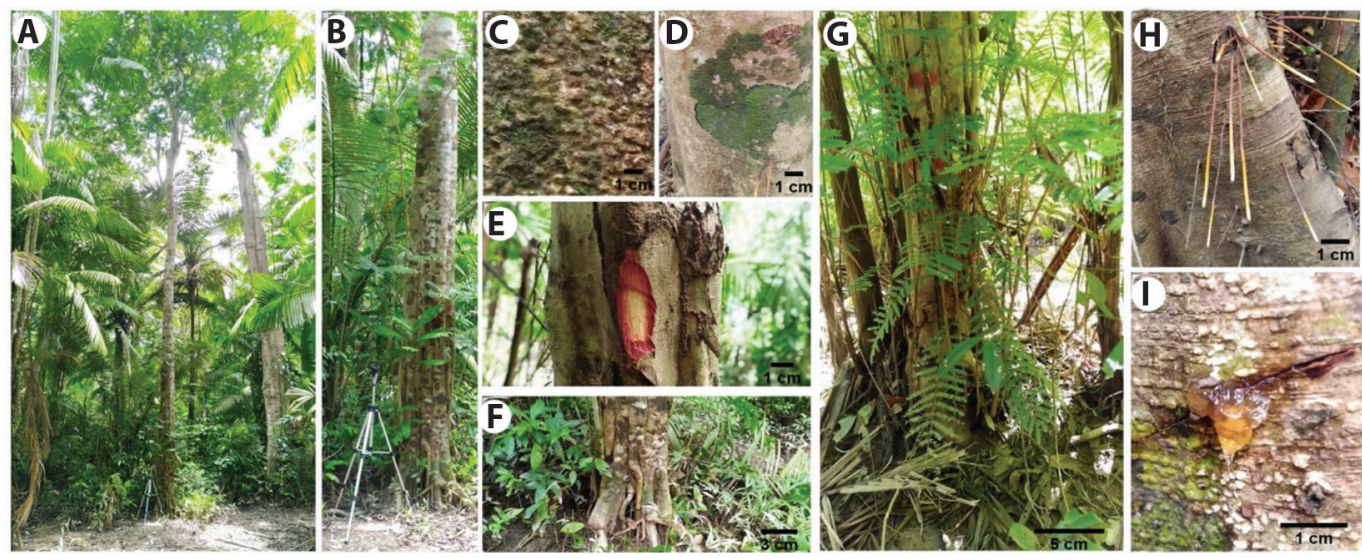

Fig. 1. Morphological characteristics of adult individuals of Pentaclethra macroloba in the Amazon estuary: A. Pentaclethra macroloba tree, B. Straight trunk, C. Protuberant lenticels on the trunk, D. Moss and lichen stain, E. Red phloem and yellow sapwood, F. Base of the trunk, G. Spread of branches at the base of the trunk, H. Adventitious roots and I. Exudate on the trunk. 

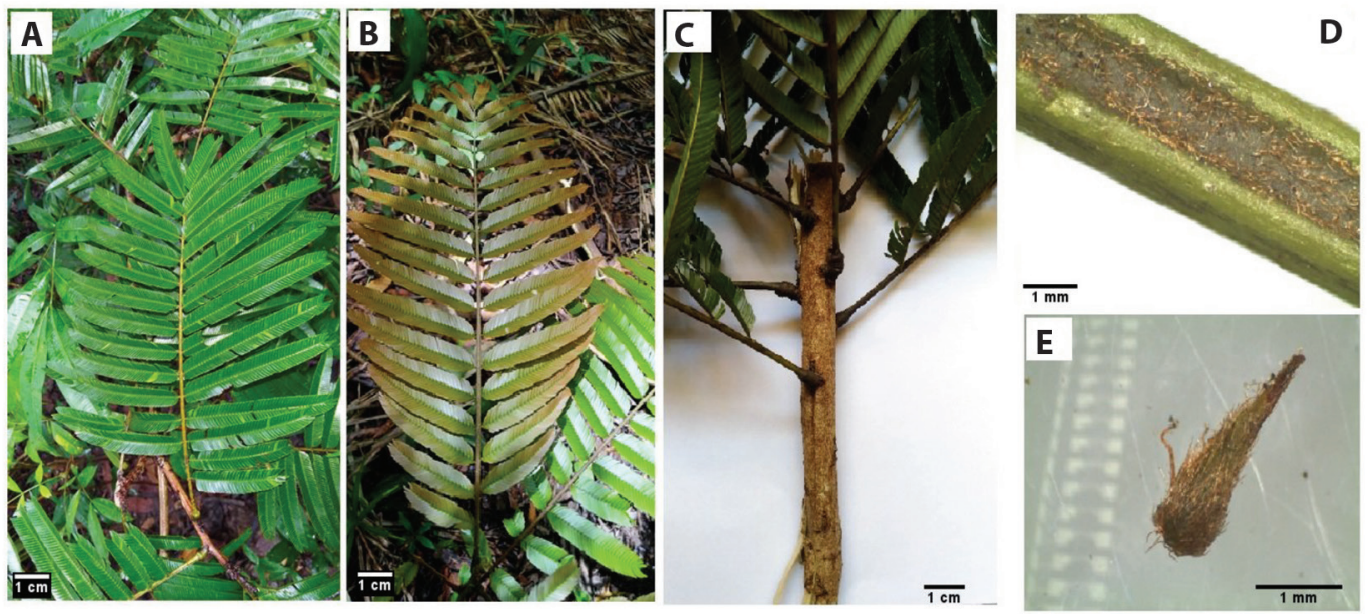

Fig. 2. Morphological characteristics of the Pentaclethra macroloba leaf in the Amazon estuary: A. Ripe leaf, A. New leaf, C. Alternate spiral phyllotaxy, D. Petiole channeled with trichomes and E. Pulvinus base stipule.

have a light red colour (Fig. 2B) and when ripe, they have a dark green colour (Fig. 2A). The leaflets $(8.6 \pm 2.8 \mathrm{~cm})$ are opposite or subopposite, containing 28-45 pairs of pinnules. The pinnules $(11.7 \pm 0.6 \mathrm{~mm})$ are opposite, oblong or linear, with an obtuse/asymmetric base; acute apex, mucronate and with the entire blade margin. The pinnules are coriaceous, dark green on the adaxial side, light green abaxial and glabrous on both sides. The petiole (32.6 \pm $10.6 \mathrm{~mm}$ ) varies from yellowish green to blackish brown, smooth to slightly rough, channelled and covered by abundant trichomes (Fig. 2D). The pulvinus $(7.5 \pm 1.4 \mathrm{~mm})$ varies from dark green to black, rough and with trichomes. The rachis $(16.6 \pm 5.8 \mathrm{~cm})$ varies from yellowish green to blackish brown colour, channelled and with trichomes similar to the petiole. The pulvinule $(1.7 \pm 0.3 \mathrm{~mm})$ is rough and varies from yellowish green to blackish brown colour. The rachilla has yellowish green or blackish brown colour, smooth and with brownish trichomes. Presence of a pair of linear stipules (Fig. 2E) at the base of the pulvinus.

The inflorescence $(17.1 \pm 3.9 \mathrm{~cm})$ is a terminal spike of white colour, due to the presence of numerous whitish staminodes (Fig. 3A). A spike can have up to 411 flowers. The floral
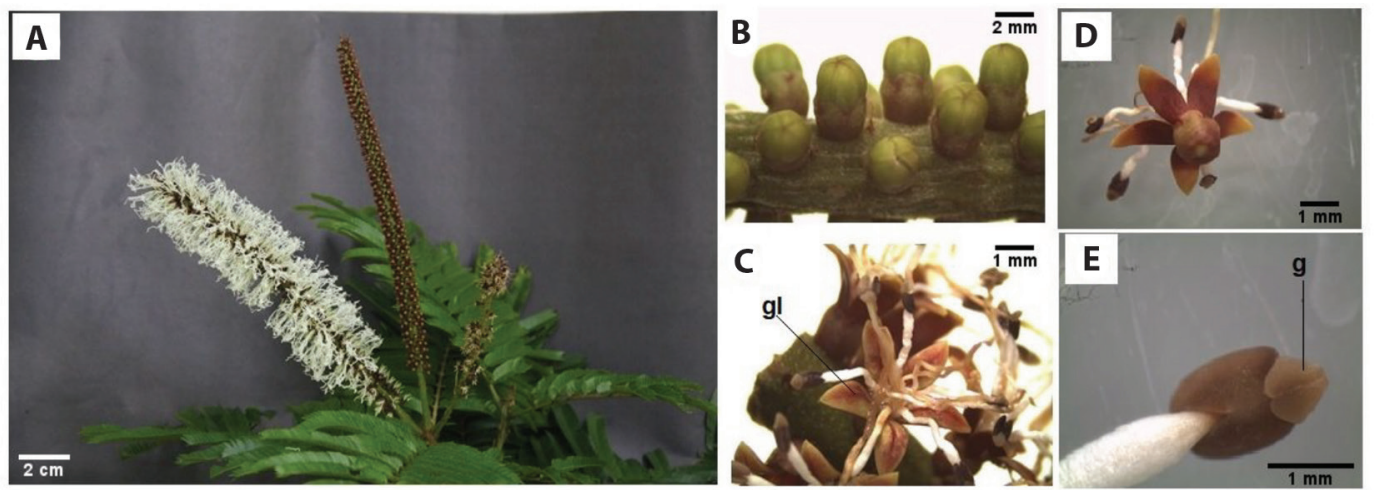

Fig. 3. Morphological characteristics of the Pentaclethra macroloba inflorescence in the Amazon estuary: A. Inflorescences in the phase of floral bud and anthesis, A. Immature flower buds, C. Pentamer flower with their guiding lines [gl] of pollinators, D. Gomosepalous calyx and E. Gland $[\mathrm{g}]$ in the anther. 
bud $(4 \pm 1.1 \mathrm{~mm})$ is initially light green when immature (Fig. 3B), becoming light green to light brown with maturation. The flower (7.2 \pm $1.3 \mathrm{~mm}$ ) is pentamer (Fig. 3C), calyx gamosepalous (Fig. 3D) and presenting up to 10 staminodes. The stamen has a gland at the tip of the anther (Fig. 3E). The petals have floral nectar guide that direct the pollinator into the flower (Fig. 3C).

Morphometry and characterization of fruits and seeds: The fruit has an average length of $33.7 \mathrm{~cm}( \pm 3.3 \mathrm{~cm})$ and weight of $105.1 \mathrm{~g}$ ( $\pm 32.3 \mathrm{~g})$ (Table 1$)$. The average number of seeds per fruit was four seeds $( \pm 1$ seed) (Table 1). Fruit length (mm) had a positive linear relationship between the measures of fresh weight $\left(\mathrm{F}=5.11 ; \mathrm{p}=0.031 * ; \mathrm{R}^{2}=0.14\right.$; Fig. 4A), length $\left(\mathrm{F}=17.48 ; \mathrm{p}=0.0002 * * * ; \mathrm{R}^{2}\right.$ $=0.37$; Fig. 4B $)$, width $\left(\mathrm{F}=59.2 ; \mathrm{p}=0.023^{*}\right.$; $\mathrm{R}^{2}=0.16$; Fig. $\left.4 \mathrm{C}\right)$ and thickness $(\mathrm{F}=9.11 ; \mathrm{p}=$ $0.005^{* *} ; \mathrm{R}^{2}=0.23$; Fig. 4D) of the seeds.

The seed has an average length of $4.4 \mathrm{~cm}$ $( \pm 0.48 \mathrm{~cm})$ and weight of $6.8 \mathrm{~g}( \pm 2.2 \mathrm{~g})$ (Table 1). Fresh mass ( $\mathrm{g}$ ) of seeds has a positive linear relationship with its measures of length $(\mathrm{F}$ $=116.23 ; \mathrm{p}<0.001 * * * ; \mathrm{R}^{2}=0.67$; Fig. 4E), width $\left(\mathrm{F}=53.01 ; \mathrm{p}<0.001 * * * ; \mathrm{R}^{2}=0.48\right.$; Fig. $4 \mathrm{~F})$ and thickness $\left(\mathrm{F}=56.48 ; \mathrm{p}<0.001 * * * ; \mathrm{R}^{2}\right.$ $=0.50$; Fig. $4 \mathrm{G})$.
The fruit is of the dry legume type (Fig. 5A), dehiscent, with 4-6 valves, light green (immature) to dark brown (ripe), laterally flattened and falcate, with an acute apex and with cuneate or attenuate base. The ventral suture is slightly flat. The pericarp is woody; externally corrugated, glabrous, rare punctiform or elliptical lenticels; internally reddish brown, slightly striate, glabrous and with diagonal cracks due to the natural twist for opening and releasing the seeds.

The seed is deltoid, rhomboid or obovoid (Fig. 5B), with flat and irregular surface, dark brown, opaque, striate and with thin grooves. The coat $(<1 \mathrm{~mm})$ varies from light brown to dark brown and opaque. Cotyledons are fleshy, light yellow to whitish colour and with channels that exude oil of rapid oxidation when exposed to air. The seed embryo has a straight embryonic axis, with well-developed plumule and radicle (Fig. 5C). The seeds have an air pocket between the cotyledons, which allows floating in water (Fig. 5D).

The average time of the fruit and seed maturation was 5 months ( \pm 3 months) and 3 months ( \pm 2 months), respectively. We recorded the formation of up to five fruits per inflorescence. First fruit arise from the 22nd day after flower fertilization (Fig. 6A). At this stage, it is still possible to observe the persistence of

TABLE 1

Morphometric values of the measured variables in fruits $(\mathrm{N}=22)$ and seeds $(\mathrm{N}=60)$ of Pentaclethra macroloba in the Amazon estuary

\begin{tabular}{lccccc} 
& Average & Standard deviation & *CV \% & Minimum & Maximum \\
Fruit & & & & & \\
$\quad$ Fresh weight $(\mathrm{g})$ & 105.1 & 32.3 & 30.7 & 50.5 & 201.7 \\
Length $(\mathrm{cm})$ & 33.7 & 3.3 & 9.9 & 22.4 & 40.8 \\
Width $(\mathrm{cm})$ & 4.2 & 0.35 & 8.1 & 3.6 & 4.9 \\
Thickness (mm) & 1.4 & 0.25 & 17.1 & 0.99 & 1.8 \\
$\quad$ Number of seeds & 4.3 & 1.1 & 26.0 & 2 & 7 \\
Seed & & & 33.0 & 2.1 & 12.1 \\
Fresh weight (g) & 6.8 & 2.2 & 10.8 & 3.3 & 5.7 \\
Length (mm) & 4.4 & 0.5 & 16.2 & 1.8 & 4.9 \\
Width (mm) & 3.1 & 0.5 & 16.3 & 0.6 & 1.3 \\
Thickness (mm) & 1 & 0.16 & & & \\
\hline
\end{tabular}

$* \mathrm{CV}=$ coefficient of variation. 

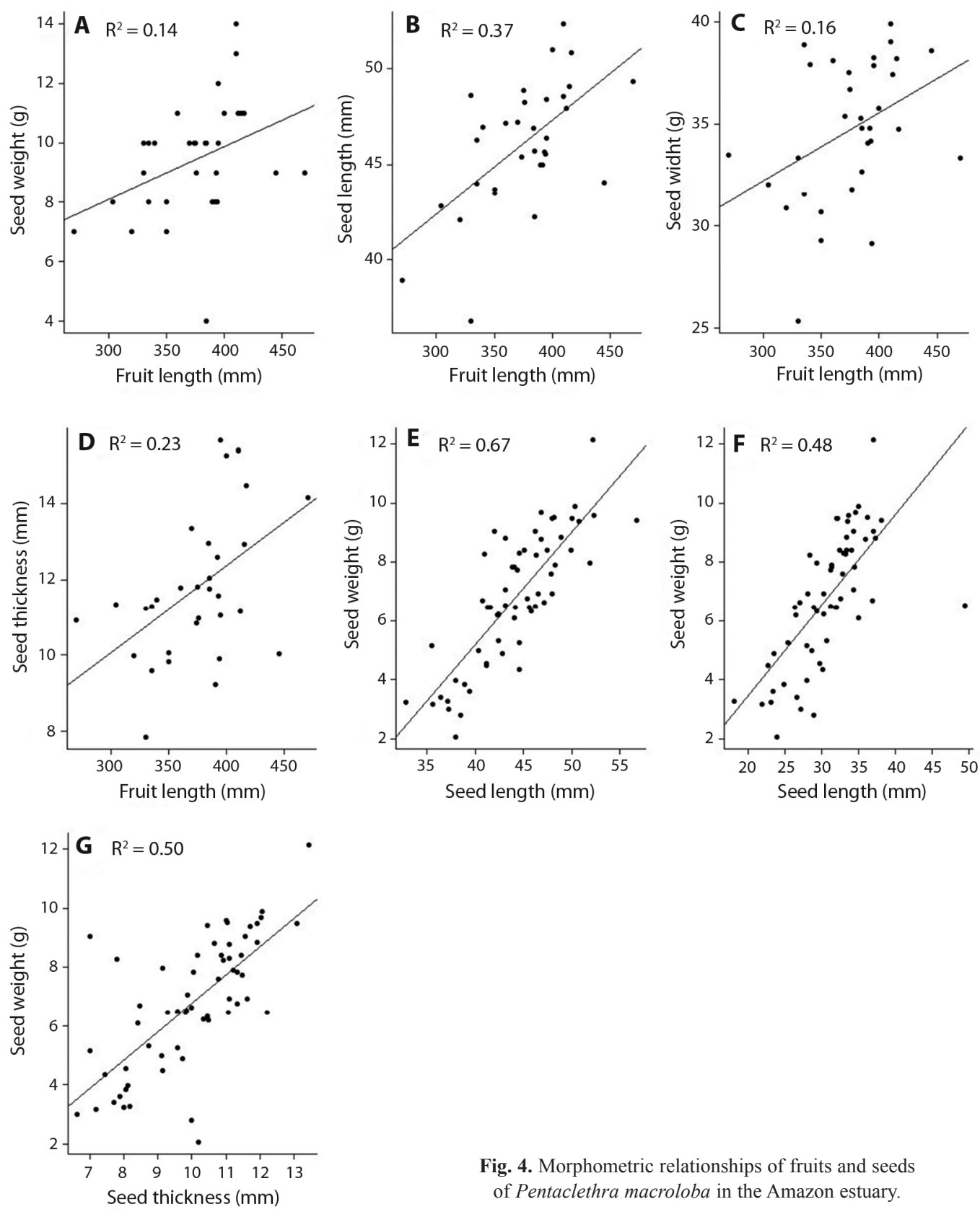

Fig. 4. Morphometric relationships of fruits and seeds of Pentaclethra macroloba in the Amazon estuary.

the calyx and corolla. On the 32nd day, the perianth disappears, the fruit gains length and falcate shape, presenting light red colour in the centre and pale green colour at the edges. (Fig. 6B). On the 53rd day, the fruit has a pale green colour, membranaceous consistency and the first light green seed appears (Fig. 6C). On the 78th day, the fruit has a light green colour, with slightly blackened edges, slightly woody consistency and with protuberances (valves) on the surface, due to the development and expansion of the light beige seeds (Fig. 6D). 


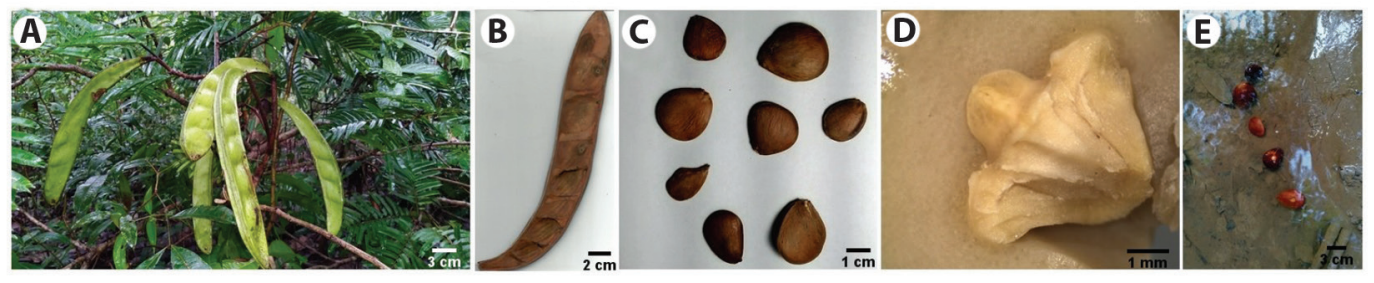

Fig. 5. Morphological characteristics of fruits and seeds of Pentaclethra macroloba in the Amazon estuary: A. Immature fruits, B. Ripe fruit with its valves, C. Ripe seeds, D. Seed embryo and E. Seeds floating in the water of the Amazon river.

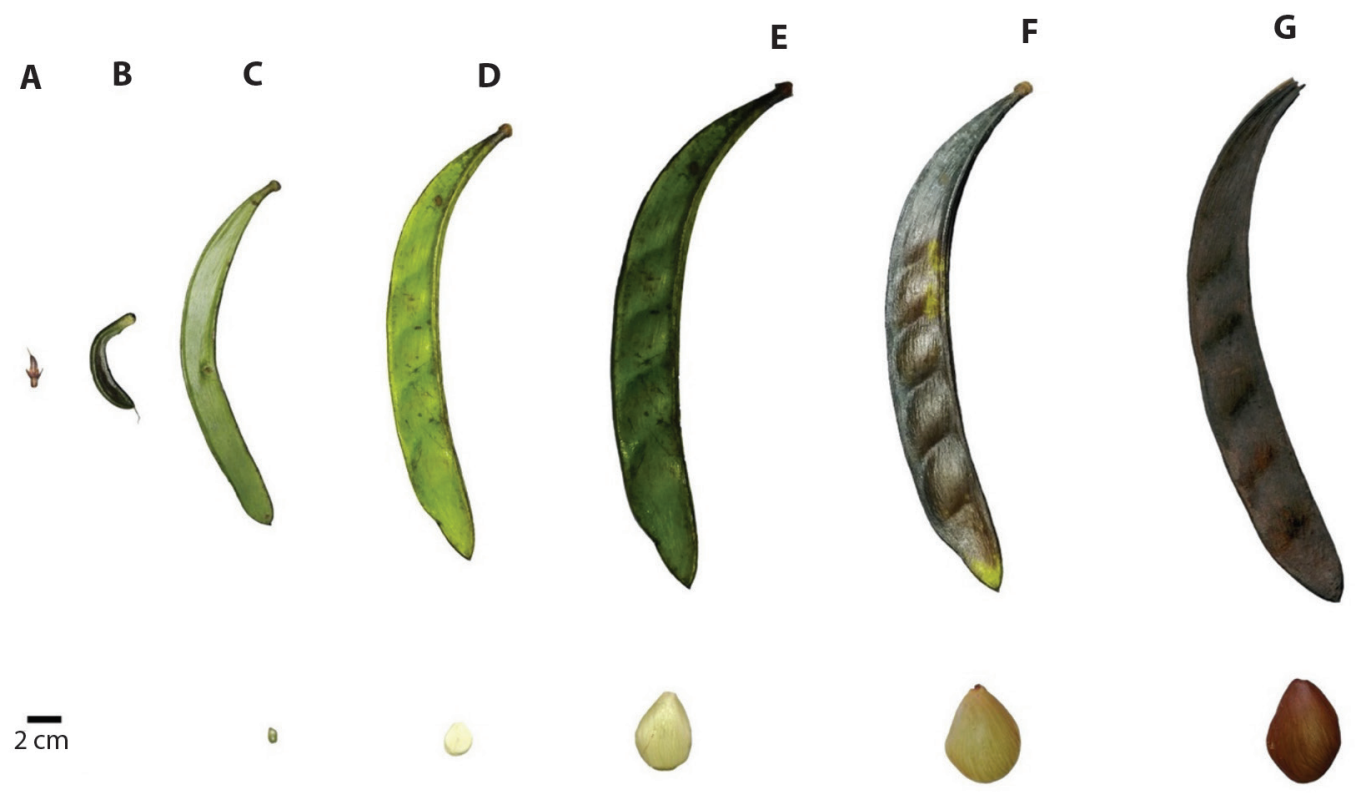

Fig. 6. Maturation phases of fruits and seeds of Pentaclethra macroloba in the Amazon estuary. Evolution of shape, size and colour: phase A. 22nd day after flower fertilization; phase B. 32nd day; phase C. 53rd day; phase D. 78th day; phase E. 110th day; phase F. 144th day; and phase G. 198th day of maturation.

On the 110th day, the fruit has a dark green colour, with blackening from the border to the centre, woody consistency and the seed has beige colour with light brown tones (Fig. 6E). On the 144th day, the fruit has brown colour, with some parts still green, woody consistency and slightly dry and the seed has light brown colour (Fig. 6F). On the 198th day, the fruit is ripe, ready to disperse the ripe seeds (Fig. 6G).

Germination and initial seedling development: The first seeds germinated on the 28th day (44 \pm 27 days) after sowing and the seedling phase on the 51st after sowing and germination. Germination is hypogeal, phanerocotylar and unipolar, with an axis between the cotyledons. During germination, the seed coat breaks, and the primary root emerges (Fig. 7A). The cotyledons open forming an acute to right angle, with the epicotyl appearing (Fig. 7B). The epicotyl lengthens and the first pair of leaves appearing (opposite or sub-opposite; Fig. 7C), which soon produces the subsequent leaves (Fig. 7D, Fig. 7E). Germination rate 


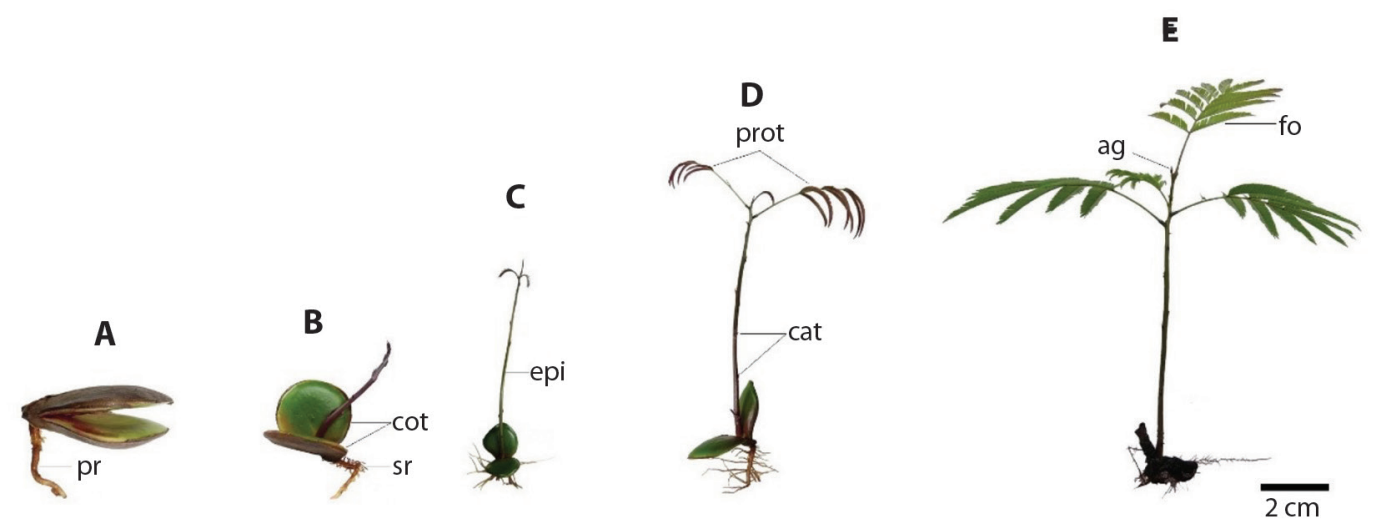

Fig. 7. Phases of seedling development of Pentaclethra macroloba in the Amazon estuary: phase A. Primary root (pr) formation; phase B. Opening of the cotyledons (cot) and formation of secondary roots (sr); phase C. Expansion of the epicotyl (epi); phase D. Development of the first leaves (prot) and formation of cataphyll (cat) in the epicotyl; and phase E. Ripe leaflets (fo) and apical bud (ag).

was $78 \%$, with average germination time of 54 days and the average germination speed was 0.2 seeds.day ${ }^{-1}$.

Seedling morphology: Seedling (Fig. 7D) has hypocotyl not elongate; cotyledons with reserves, asymmetrical, internally dark green and externally brownish green, with longitudinal grooves becoming rough over time. The epicotyl $(17.7 \pm 3.7 \mathrm{~cm})$ is initially greenish, becoming violet to brownish, smooth to slightly rough, striate longitudinally, with yellow translucent trichomes and with abundant circular and punctate lenticels. Presence of 11-13 triangular cataphylls $(1.7 \pm 0.6 \mathrm{~mm})$ along the epicotyl.

First pair of leaves $(15.7 \pm 4.4 \mathrm{~cm})$ are bipinnate, opposite, sub-opposite or alternate, often paripinnate and rarely imparipinnate and with 6-12 opposite leaflets. The pinnules (9.2 $\pm 0.4 \mathrm{~mm}$ ) are sessile, oblong, papyraceous, with obtuse and asymmetric base, acute and mucronate apex and margin of the entire and ciliate blade (yellowish trichomes). The petiole $(3.8 \pm 1.2 \mathrm{~cm})$ is brownish green, with trichomes, smooth or rough, with wing and flat or channelled. Discolour leaf blade, with dark green adaxial face and light green abaxial face. The rachis $(6.6 \pm 2.4 \mathrm{~cm})$ is brownish-green, smooth to rough, apiculate and with trichomes similar to the petiole, but more abundant. The pulvinus $(3.3 \pm 0.8 \mathrm{~mm})$ is dark green, rough, with trichomes equal to that of the petiole and with transverse fissures. Presence of a pair of stipules at the base of the pulvinus (Fig. 8B). Glands or extrafloral nectary at the base of the pulvinus (Fig. 8C). The petiole is reduced to pulvinule $(0.6 \pm 0.2 \mathrm{~mm})$.

Subsequent leaves $(10.4 \pm 1.7 \mathrm{~cm})$ are equal to the first leaves, but smaller in size, with alternate spiral phyllotaxy (Fig. 8A) and have 9 to 16 leaflets. The pinnules $(7.4 \pm 2.1$ $\mathrm{mm}$ ) is equal to the first leaves, but larger. The petiole $(3.8 \pm 1.2 \mathrm{~cm})$ is equal to the first leaves, but smaller. The rachis $(6.6 \pm 2.3 \mathrm{~cm})$ is equal to the first leaves. The pulvinus $(3.2 \pm 0.8$ $\mathrm{mm}$ ) is equal to the first leaves. The petiolule is reduced to pulvinule. The pulvinule $(0.6 \pm$ $0.2 \mathrm{~mm}$ ) is equal to the first leaves. Conduplicate prefoliation, from violet to reddish-brown colour and with translucent trichomes. The internodes have lenticels similar to the epicotyl, but more abundant.

Geographic distribution: We analysed 210 points of geographical coordinates of digital botanical collections. The centre of occurrence of $P$. macroloba was throughout Latin America, showing that it is a neotropical species (Fig. 9). Data from digital repositories 

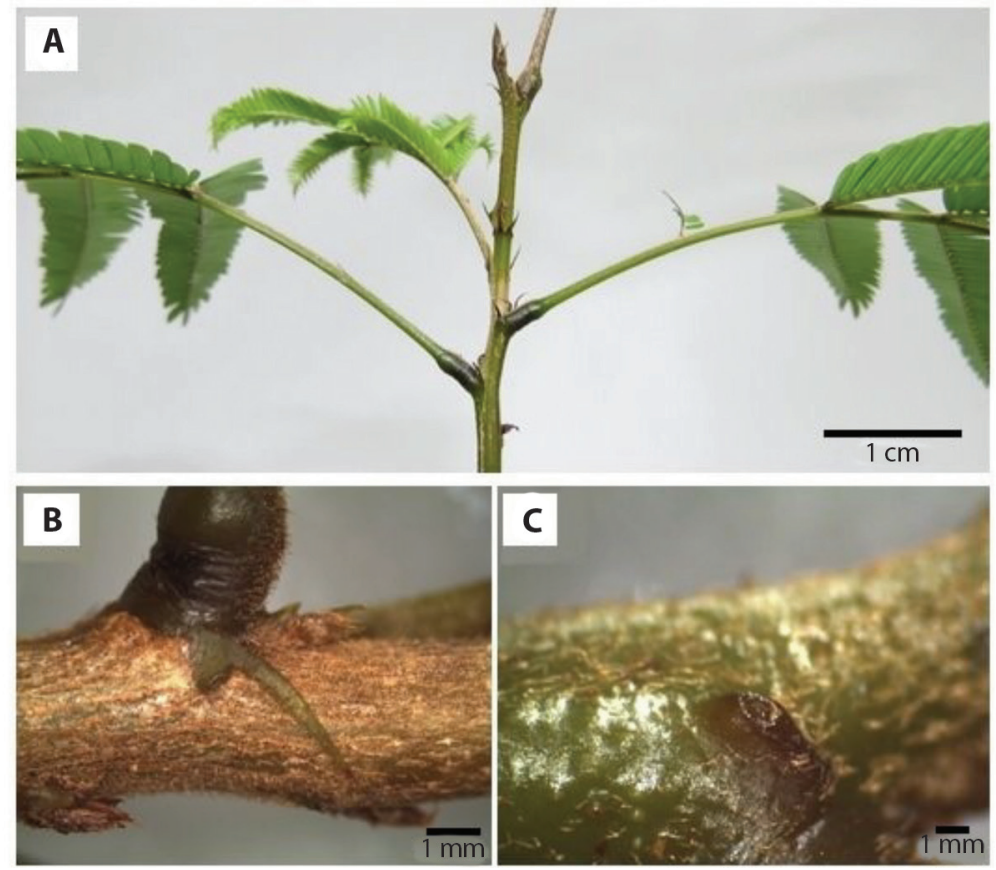

Fig. 8. Morphological characteristics of Pentaclethra macroloba seedling in the Amazon estuary: A. Phyllotaxy of the subsequent leaves, B. Stipule at the base of the pulvinus and C. Gland at the lateral base of the pulvinus.

show the presence of P. macroloba in Guatemala, Costa Rica, Panama, Colombia, Venezuela, Trinidad and Tobago, Guyana, French Guyana Suriname, and Brazil. In Brazil, the species is endemic to the Amazon biome and its dispersion area comprises the states of Acre, Amazonas, Roraima, North Mato Grosso, Amapá and Pará.

The species has 123 subpopulations (Fig. 9) distributed on a radius of 5699943 $\mathrm{km}^{2}$ along its extent of occurrence. The area of occupation of a species represents its suitable habitat, for P. macroloba is $9990 \mathrm{~km}^{2}$.

\section{DISCUSSION}

The individuals described in this study appear to be medium size compared to individuals of $P$. macroloba from Central America, where populations are more robust (Hartshorn, 1983). In Costa Rica, adult individuals occupy the canopy of the forest, reaching a height of 25 to $35 \mathrm{~m}$ and with diameter reaching up to $130 \mathrm{~cm}$ (Flores, 2003). In South America, in the forests of the department of Chocó (Colombia), the majority of individuals occupy the sub-canopy forest, with a maximum diameter of $65 \mathrm{~cm}$ (Hartshorn, 1983). In general, the population of $P$. macroloba located in the Amazon forest is of medium height (Hartshorn, 1983), as presented the individuals in this study with a maximum diameter of $59 \mathrm{~cm}$. This shows evidence that individuals in the Amazon estuary invest more resources to gain height, as the maximum height $(37 \mathrm{~m})$ found was greater than other studies. According to Parolin (2002), the trees of the Amazon floodplain forests need to increase the maximum height to escape the flood.

External morphological structures shown by $P$. macroloba, evidence an adaptive relationship to the periodically flooded environment of the Amazon estuary. In response to flooding, adventitious roots are produced during the flood season in the Amazon river (from January to March influenced by the rainy season), 

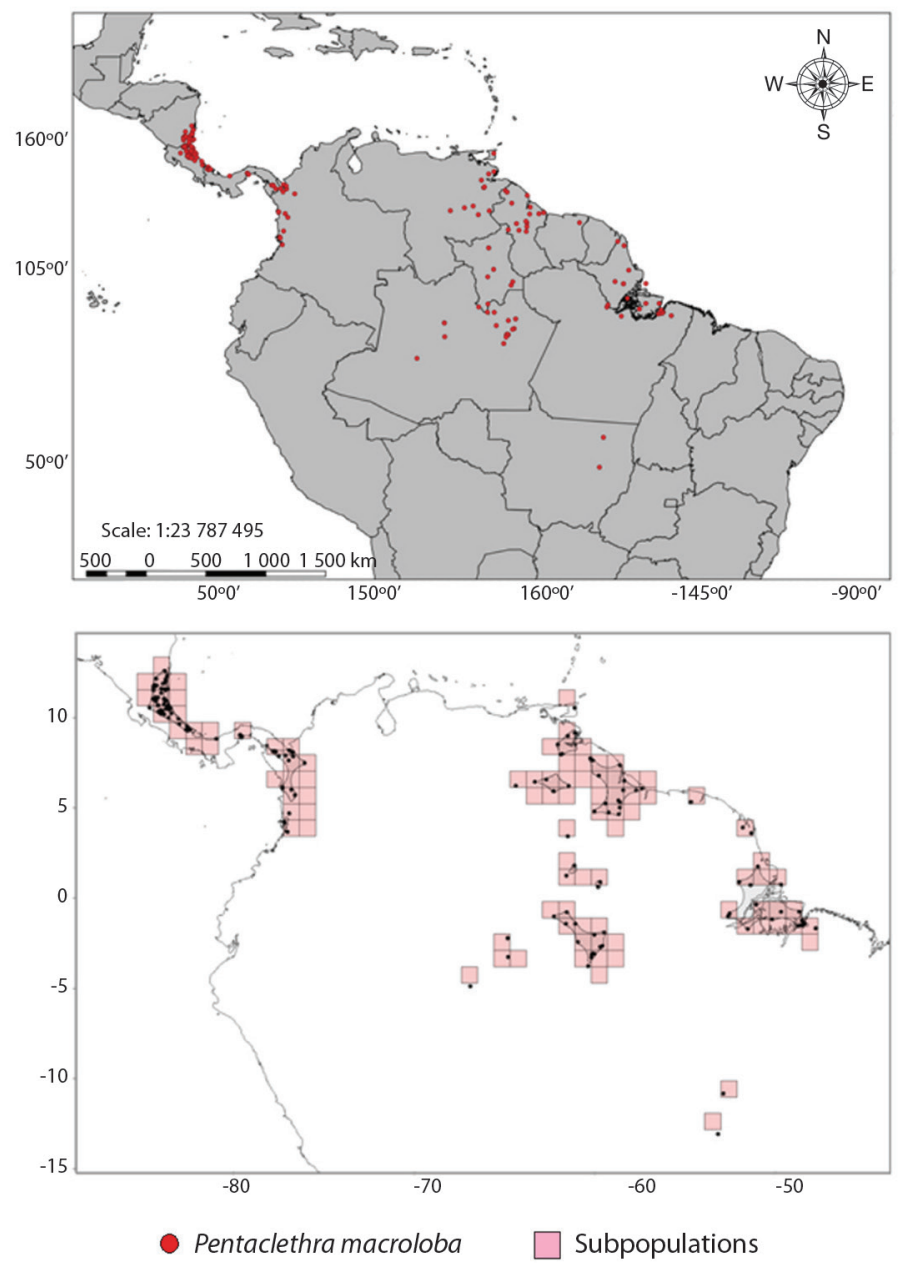

Fig. 9. Dispersion area (above) and number of subpopulations (below) of Pentaclethra macroloba in the Neotropical region (Data source: tropicos.org and splink.cria.org.br).

decreasing in the dry season (from September to December). This characteristic presented by P. macroloba is a morphological adaptation to the periodically flooded environment, because the adventitious roots increase the energetic and respiratory efficiency of the plant (Haase, Simone, \& Junk, 2003) when the rhizosphere has low oxygen concentration. Individuals of P. macroloba from some regions of Costa Rica also have adventitious roots in flooded environments (Walter \& Bien, 1989).

Reproductive strategies can also be observed in P. macroloba. A characteristic that calls attention in P. macroloba is the spread of several branches at the base of its trunk (Fig. $1 \mathrm{G})$. According to Gaddis, Zukin, Dieterich, Braker, and Sork (2014), P. macroloba has a high power of vegetative propagation (clonal reproduction), even if the tree is down, there are numerous sprouts of branches on the trunk and roots. This strategy is efficient in periodically flooded environments, because a faster increase in height prevents the plant from being submerged and has its productivity limited by the flood (Parolin, 2002).

The species has nectar guides on its petals to increase pollen efficiency. Nectar guides are floral traits that some superior plants have 
to attract the attention of effective pollinators (Leonard, Brent, Papaj, \& Dornhaus, 2013). The nectar guide on the $P$. macroloba petal attracts and directs pollinators into the corolla, where is the nectar gland at the base of the ovary (Barros, Pedersoli, Paulino, \& Teixeira, 2017), increasing the chances of fertilization of the ovule.

Morphological characteristics presented in the fruits and seeds of $P$. macroloba are adaptive evidence in search of greater efficiency in the seed dispersal. The low moisture content that the fruit has when ripe (dry fruit), favours the activation of the explosive dehiscence mechanism (the ventral suture and the valves) for the seeds to be expelled (Williamson \& Costa, 2000) at a distance of up to $10 \mathrm{~m}$ out of the tree canopy (Hartshorn, 1983). The flattened shape (deltoid), together with the accumulation of air between the cotyledons (Soares, Santos, $\&$ Silva, 2019) and the specific gravity of the seed (Williamson \& Costa, 2000), allows the seed to float in the water of the Amazon estuary, achieving greater efficiency in dispersion.

Positive linear relationship between the length of the fruit and the measures of weight, length and thickness of the seeds, give clue that P. macroloba invests in resources to produce seeds with high energy content. This strategy allows the seedlings to survive the adverse conditions of the flooded environment. According to Primack (1987), bulky seeds have high reserve content in their cotyledons, allowing the seedling to obtain an extra energy source for a long period.

This study showed that the size of the fruit is a good predictor for selecting seeds with higher fresh weight, this characteristic is important for the management of oil extraction from Pracaxi. The experience of riverine people in oil extraction shows that larger seeds yield a greater amount of oil, compared to smaller seeds (in conversation with some riverine people from the Bailique community, Amapá, Brazil). This linear trend to produce larger fruits and have larger seeds, can be related to a more lasting source of nutrients for the plants. Large seeds have greater amounts of nutritive reserves for the development of the plant and help to supply the lack of photosynthetic tissue in the early stages of the seedling's life (Parolin, 2002).

The germination rate of $P$. macroloba shows variability in different flooded environments in the Amazon. In this study, estuarine floodplain forest, the germination rate found was $78 \%$. In the igapó forest of Central Amazonia, Parolin, Ferreira, and Junk (2003) found a germination rate for P. macroloba of $45 \%$. The two environments differ, among other factors, by the nutritional status of the soil. The Amazon estuary is bathed by a river containing high load of sedimentary and nutritional material, which are deposited in the soil of this environment. The igapós of the Amazon are of older geological origin and are bathed by rivers of black water, with a high load of plant material in decomposition, of low nutritional fertility (Junk et al., 2011).

Hypogeal germination presented by $P$. macroloba is common among Amazonian floodplain species (Parolin et al., 2003) and among native Amazonian legumes (Moreira \& Moreira, 1996). This type of germination is related to the size of the seedling. Species with hypogeal germination have seedlings eight times larger than species of epigeal germination, both types of germination help the seedlings to survive long periods of flooding (Parolin et al., 2003). Melo, Franco, Silva, Piedade, \& Ferreira (2015) emphasize that the germination of the type epigeal phanerocotylar is an adaptive strategy for obtaining light and $\mathrm{CO}_{2}$ in a short period of time.

Seedlings of $P$. macroloba produce numerous lenticels in the epicotyl, fact also observed by Parolin (2001) in floodplain seedlings in the Central Amazon. Lenticels are essential in flooded environments seedlings, due to these structures facilitate the entry of oxygen and improve the internal diffusion of gas between the plant's organs (Parolin, 2012). When located above the surface of the water, lenticels are a connection point between the aerial organs and the root of the tree (Haase \& Gudrun, 2010). 
Seedlings that manifest reserve cotyledons in a flooded environment have great chances of survival in this type of environment. Cotyledon reserves guarantee rapid growth in height and the seedling can escape total submersion in its initial growth stages (Maia, Maia, \& Parolin, 2005). This strategy is efficient in the Amazon estuary, because most pracaxi seeds germinate at the end of the flood period (period that the waters recede from the interior of the forest) and develop in the drought period (dry season from September to December, where river water does not reach the interior of the forest), being sufficient for the seedling to use the cotyledon reserves and gain height to escape the flood of next year.

Dispersion area of $P$. macroloba is quite wide in the Neotropical region, allowing the species to colonize various habitats. In Costa Rica, the species is found in ancient alluvial soils of virgin or secondary forests (Hartshorn, 1983), in annual precipitation regime above $4300 \mathrm{~mm}$ and average temperature of $25{ }^{\circ} \mathrm{C}$ (Eaton et al., 2011). On the island of Trinidad, the species inhabits seasonal perennials forests with high content of clay and sand (GreigSmith, 1952). In the Amazon region, the species can colonize in flooded and non-flooded environments. Dense populations of the species can be found in clayey latosolic soils of the dense non-flooded ombrophilous forest (Condé \& Tonini, 2013). In Central Amazonia, P. macroloba is not dominant, but it tolerates lasting flooding up to $14 \mathrm{~m}$ in height and poor soils in the igapó forests (Ferreira \& Parolin, 2007). P. macroloba dominates estuarine floodplain forests (Carim et al., 2016), areas with high sedimentary load, rich in nutrients and low amplitude of flooding (Junk et al., 2014).

The circular buffer method detected the presence of 123 subpopulations of $P$. macroloba widely distributed in the Neotropical region. Hartshorn (1983) considers the presence of three large populations of $P$. macroloba distributed in Latin America. According to the author, the first population, widely studied, occurs initially in the coastal region of Western Nicaragua, passing through Costa Rica and taking the Western part of Panama. The second population occurs in the West of the department of Chocó, Colombia and in the humid part adjacent to the Darien province of Panama. The third population is found in Northeast Venezuela, the island of Trinidad, the Guianas and the Amazon Basin. The author considers the necessity for further studies aimed at the population of the Amazon Basin, since this population is little known in the scientific community.

Considering the Amazon region, P. macroloba presents a pattern "centered in the Amazon" proposed by Gentry (1981). The pattern centered in the Amazon is characterized by having a high density of species in the Amazon Basin, while the pattern centered in the Andes has its centre of diversity on the border of Central America with North-western South America (Antonelli \& Sanmartín, 2011). Gentry (1981) explains that the centre of endemism for some species in the Amazon was influenced by changes that occurred in the Pleistocene (theory of Pleistocene forest refuges). Drastic climate fluctuations in the Pleistocene period caused the fragmentation and coalescence of tropical forests, resulting in the isolation and speciation of large forest populations (Connor, 1986). Several theories emerged to explain the diversity and distribution pattern of tropical species (Antonelli \& Sanmartín, 2011), however, some knowledge gaps remain unanswered, requiring in-depth studies on the topic.

External morphological characteristics of P. macroloba shows evolutionary and adaptive evidence of the species in response to the dynamics and the varied flooding amplitudes of the Amazon floodplain forests. The plasticity of adaptation to different habitats may explain the dominance of this species and its centre of diversification in the Amazon. The result of this study is essential to assist in management strategies, allowing, among others, a more precise identification of productive trees to order the collection of seeds. In the scope of public policies, the results reinforce the valorisation of non-wood forest products, orienting towards the better use of pracaxi seeds, a non-wood product of local socioeconomic importance and 
that inhabits the fragile estuarine floodplains of the Amazon.

Ethical statement: authors declare that they all agree with this publication and made significant contributions; that there is no conflict of interest of any kind; and that we followed all pertinent ethical and legal procedures and requirements. All financial sources are fully and clearly stated in the acknowledgements section. A signed document has been filed in the journal archives.

\section{ACKNOWLEDGMENTS}

We thank Programa de Pós-graduação em Ecologia (PPGEco/INPA), Instituto Nacional de Pesquisas da Amazônia (INPA), Conselho Nacional de Desenvolvimento Científico e Tecnológico (CNPq) (doctoral scholarship 142316/2016-4) and Empresa Brasileira de Pesquisa Agropecuária (Embrapa Amapá). This work was supported by the Empresa Brasileira de Pesquisa Agropecuário do Amapá through Kamukaia III project [02.13.07.007.00.00].

\section{RESUMEN}

Morfología, germinación y distribución geográfica de Pentaclethra macroloba (Fabaceae): árbol amazónico hiperdominante. Introducción: Pentaclethra macroloba es un árbol hiperdominante en el estuario del Amazonas, de gran importancia socioeconómica para la región, pues el aceite de sus semillas es un poderoso medicamento natural. Objetivo: Nuestro objetivo fue caracterizar la estructura morfológica, las adaptaciones morfológicas en respuesta a las inundaciones diarias del estuario del Amazonas y el área biogeográfica de $P$. macroloba. Métodos: Una descripción detallada de la morfología externa, desde la germinación hasta el árbol adulto, se obtuvo de individuos ubicados en el bosque periódicamente inundado, al noreste de la Amazonia. El área de ocupación y la extensión geográfica de $P$. macroloba se determinaron a partir del punto de coordenadas geográficas de muestras botánicas depositadas en las colecciones digitales de Mobot y SpeciesLink. Resultados: Los individuos adultos tienen estructuras adaptadas en respuesta a las inundaciones diarias, tales como: raíces adventicias para aumentar la eficiencia respiratoria y lenticelas en el tronco, que sirven como punto de conexión para el transporte de oxígeno entre la raíz y la parte aérea. Los frutos secos favorecen la activación del mecanismo de dehiscencia explosiva, permitiendo que la semilla sea expulsada a larga distancia. La forma deltoidea de la semilla permite la fluctuación en el agua y una dispersión más eficiente. La plántula es hipogel fanerocotiledones y con un par de cotiledones de reserva que proporcionan a la plántula una fuente extra de energía para escapar de la inundación. La tasa de germinación fue del 78 $\%$ y la velocidad fue de 0.2 semillas día $^{-1}$. El método Circular buffer reveló la presencia de 123 subpoblaciones de $P$. macroloba distribuidas en un radio de $5699943 \mathrm{~km}^{2}$ a lo largo de la región neotropical. Conclusiones: Gran parte de las estructuras morfológicas de P. macroloba son respuestas adaptativas y evolutivas al ambiente periódicamente inundado del estuario del Amazonas, lo que demuestra que estos ambientes actúan como filtro ambiental seleccionado las especies mejor adaptadas al medio. Su amplia área geográfica denota la plasticidad de adaptarse a diferentes ambientes, lo que puede justificar su monodominancia en algunas regiones.

Palabras clave: adaptación morfológica; inundaciones por mareas; árbol neotropical; raíces adventicias; aceite de pracaxi; manejo, conservación.

\section{REFERENCIAS}

Almeida, S.S., Amaral, D.D., \& Silva, A.S.L. (2004). Análise florística e estrutura de florestas de várzea no estuário amazônico. Acta Amazonica, 34(4), 513-524.

Alvares, C.A., Stape, J.L., Sentelhas, P.C., Gonçalves, J.L.M., \& Sparovek, G. (2013). Köppen's climate classification map for Brazil. Meteorologische Zeitschrift, 22(6), 711-728.

Antonelli, A., \& Sanmartín, I. (2011). Why are there so many plant species in the Neotropics? TAXON, 60(2), 403-414.

Barros, T.C., Pedersoli, G.D., Paulino, J.V., \& Teixeira, S.P. (2017). In the interface of Caesalpinioids and Mimosoids: Comparative floral development elucidates shared characters in Dimorphandra mollis and Pentaclethra macroloba (Leguminosae). American Journal of Botany, 104(2), 218-232.

Barroso, G.M., Morim, M.P., Pioxoto, A.L., \& Ichaso, C.L.F. (2004). Frutos e sementes: morfologia aplicada à sistemática de dicotiledôneas. Viçosa, Brasil: Universidade Federal de Viçosa.

Camargo, J., Ferraz, I., Mesquita, M., Santos, B., \& Brum, H. (2008). Guia de propágulos e plântulas da Amazônia. Manaus, Brasil: Instituto Nacional de Pesquisas da Amazônia.

Carim, M.J.V., Wittmann, F.K., Piedade, M. T. F., Guimarães, J.R.S., \& Tostes, L.C.L. (2016). Composition, diversity, and structure of tidal "Várzea" and 
"Igapó" floodplain forests in Eastern Amazonia, Brazil. Brazilian Journal of Botany, 40(1), 115-124.

Condé, T.M., \& Tonini, H. (2013). Fitossociologia de uma Floresta Ombrófila Densa na Amazônia Setentrional, Roraima, Brasil. Acta Amazonica, 43(3), 247-260.

Connor, E.F. (1986). The role of Pleistocene forest refugia in the evolution and biogeography of tropical biotas. Trends in Ecology and Evolution, 1(6), 165-168.

Costa, M.N.F.S., Muniz, M.A.P., Negrão, C.A.B., Costa, C.E.F., Lamarão, M.L.N., Morais, L., ... Costa, R.M.R. (2014). Characterization of Pentaclethra macroloba oil. Journal of Thermal Analysis and Calorimetry, 115(3), 2269-2275.

CRIA (Centro de Referência e Informação Ambiental). (2019). speciesLink is a distributed information system that integrates primary data from biological collections. Retrieved from http://splink.cria.org.br

Dantas, A.R., Marangon, L.C., Guedes, M.C., Feliciano, A.L.P., \& Lira-Guedes, A.C. (2017). Spatial distribution of a population of Pentaclethra macroloba (Willd.) Kuntze in a floodplain forest of the Amazon estuary. Revista Árvore, 41(4), 1-11.

Dauby, G. (2019). ConR: Computation of Parameters Used in Preliminary Assessment of Conservation Status (Version 1.3.0, R Package) Retrieved from https:// CRAN.R-project.org/package $=$ ConR

De Simone, O., Junk, W.J., \& Schmidt, W. (2003). Central Amazon floodplain forests: Root adaptations to prolonged flooding. Russian Journal of Plant Physiology, 50(3), 848-855.

Eaton, W.D., McDonald, S., Roed, M., Vandecar, K.L., Hauge, J.B., \& Barry, D. (2011). A comparison of nutrient dynamics and microbial community characteristics across seasons and soil types in two different old growth forests in Costa Rica. Tropical Ecology, 52(1), 35-48.

Ferreira, L.V., \& Parolin, P. (2007). Tree phenology in Central Amazonian floodplain forests: effects of water level fluctuation and precipitation at community and population level. Pesquisas Botânica, 58, 139-155.

Flores, E.M. (2003). Pentaclethra macroloba (Willd.) Kuntze. In J.A Vozzo (Ed.), Tropical tree: seed manual (pp. 601-604). Washington DC, USA: United States Department of Agriculture.

Gaddis, K.D., Zukin, H.L., Dieterich, I.A., Braker, E., \& Sork, V.L. (2014). Effect of clonal reproduction on genetic structure in Pentaclethra macroloba (Fabaceae: Mimosoideae) Keith. Revista de Biología Tropical, 62(2), 443-454

Gaston, K.J., \& Fuller, R.A. (2009). The sizes of species' geographic ranges. Journal of Applied Ecology, 46(1), 1-9.
Gentry, A.H. (1981). Distributional patterns and an additional species of the Passiflora vitifolia complex: Amazonian species diversity due to edaphically differentiated communities. Plant Systematics and Evolution, 137(1-2), 95-105.

Gonçalves, E.G., \& Lorenzi, H. (2011). Morfologia Vegetal: organografia e dicionário ilustrado de morfologia das plantas vasculares (2 ${ }^{\text {nd }}$ Ed.). São Paulo, Brazil: Instituto Plantarum de Estudos da Flora.

Greig-Smith, P. (1952). Ecological observations on degraded and secondary forest in Trinidad, British West Indies: I. General features of the vegetation. Journal of Ecology, 40(2), 283-315.

Haase, K., \& Gudrun, R. (2010). The morphology and anatomy of tree roots and their aeration strategies. In W.J. Junk, M.T.F. Piedade, F.K. Wittmann, J. Schöngart, \& P. Parolin (Eds.), Amazonian Floodplain Forests: Ecophysiology, Biodiversity and Sustainable Managementoodplain (pp. 141-161). Dordrecht, Netherlands: Springer Dordrecht Heidelberg London.

Haase, K., Simone, O.D.E., \& Junk, W.J. (2003). Internal oxygen transport in cutting from flood-adapted várzea tree species. Tree Physiology, 23(15), 1069-1076.

Harris, J.G., \& Harris, M.W. (2001). Plant identification terminology: an illustrated glossary (2nd ed.). Utah, USA: Spring Lake Publishing.

Hartshorn, G.S. (1983). Pentaclethra macroloba (Gavilan). In D.H. Janzen (Ed.), Costa Rican Natural History (pp. 301-303). Chicago, USA: University of Chicago Press.

IBGE - Instituto Brasileiro de Geografia e Estatística. (2012). Manual técnico da vegetação brasileira : sistema fitogeográfico : inventário das formações florestais e campestres: técnicas e manejo de coleções botânicas: procedimentos para mapeamentos $\left(2^{\text {nd }}\right.$ Ed.). Rio de Janeiro, Brasil: IBGE.

IUCN Standards and Petitions Subcommittee. (2017). Guidelines for Using the IUCN Red List Categories and Criteria. Retrieved 7 June 2019, from http://www. iucnredlist.org/documents/RedListGuidelines.pdf

Junk, W.J., Piedade, M.T.F., Lourival, R., Wittmann, F., Kandus, P., Lacerda, L.D., ... Agostinho, A.A. (2014). Brazilian wetlands: Their definition, delineation, and classification for research, sustainable management, and protection. Aquatic Conservation: Marine and Freshwater Ecosystems, 24(1), 5-22.

Junk, W.J., Piedade, M.T.F., Schöngart, J., Cohn-Haft, M., Adeney, J.M., \& Wittmann, F. (2011). A classification of major naturally-occurring amazonian lowland wetlands. Wetlands, 31(4), 623-640.

Laman, T.G. (1995). Safety recommendations for climbing rain forest trees with "Single rope technique". Biotropica, 27(3), 406-409. 
Leonard, A.S., Brent, J., Papaj, D.R., \& Dornhaus, A. (2013). Floral nectar guide patterns discourage nectar robbing by bumble bees. PLOS ONE, 8(2), 1-6.

Maguire, J.D. (1962). Speed of germination-aid selection and evaluation for seedling emergence and vigor. Crop Science, 2(2), 176-177.

Maia, L.A., Maia, S., \& Parolin, P. (2005). Seedling morphology of non-pioneer trees in Central Amazonian várzea floodplain forests. Ecotropica, 11(1-2), 1-8.

Melo, M.G.G., Mendonça, M.S., \& Mendes, A.M.S. (2004). Análise morfológica de sementes, germinação e plântulas de jatobá (Hymenaea intermedia Ducke var. adenotricha (Ducke) Lee \& Lang.) (Leguminosae-caesalpinioideae). Acta Amazonica, 34(1), 9-14.

Melo, R.B., Franco, A.C., Silva, C.O., Piedade, M.T.F., \& Ferreira, C.S. (2015). Seed germination and seedling development in response to submergence in tree species of the Central Amazonian floodplains. $A o B$ PLANTS, 7(Plv041), 1-12.

Moreira, F.M.S., \& Moreira, F.W. (1996). Características da germinação de sementes de 64 espécies de leguminosas florestais nativas da Amazônia, em condições de viveiro. Acta Amazonica, 26(1/2), 3-16.

Parolin, P.I.A., Ferreira, L.V., \& Junk, W.J. (2003). Germination characteristics and establishment of trees from Central Amazonian flood plains. Tropical Ecology, 44(2), 157-169.

Parolin, P. (2012). Diversity of adaptations to flooding in trees of amazonian floodplains. Pesquisas Botanica, $63,7-28$.

Parolin, P. (2001). Seed germination and early establishment of 12 tree species from nutrient-rich and nutrient-poor Central Amazonian floodplains. Aquatic Botany, 70(2), 89-103.

Parolin, P. (2002). Submergence tolerance vs. escape from submergence: two strategies of seedling establishment in Amazonian floodplains. Environmental and Experimental Botany, 48(2), 177-186.

Pinto, E.R. (2014). Solos, hidrologia e estrutura populacional de pracuubeiras em florestas de várzea do estuário amazônico (Master's thesis). Universidade Federal do Amapá, Macapá, Brazil.

Primack, R.B. (1987). Relationships among flowers, fruits, and seeds. Annual Review of Ecology and Systematics, 18(1), 409-430.
R core Team. (2019). R: A Language and Environment for Statistical Computing. Vienna, Austria. Retrieved from http://www.R-project.org

Rivers, M.C., Bachman, S., Meagher, T.R., Lughadha, E.N., \& Brummitt, N.A. (2010). Subpopulations, locations and fragmentation: Applying IUCN red list criteria to herbarium specimen data. Biodiversity and Conservation, 19(7), 2071-2085.

Schöngart, J., Junk, W.J., Piedade, M.T.F., Ayres, J.M., Hüttermann, A., \& Worbes, M. (2004). Teleconnection between tree growth in the Amazonian floodplains and the El Niño-Southern Oscillation effect. Global Change Biology, 10(5), 683-692.

Schöngart, J., Piedade, M.T.F., Ludwigshausen, S., Horna, V., \& Worbes, M. (2002). Phenology and stemgrowth periodicity of tree species in Amazonian floodplain forests. Journal of Tropical Ecology, 18(4), 581-597.

Silva, J.O., Fernandes, R.S., Ticli, F.K., Oliveira, C.Z., Mazzi, M.V., Franco, J.J., ... Sampaio, S.V. (2007). Triterpenoid saponins, new metalloprotease snake venom inhibitors isolated from Pentaclethra macroloba. Toxicon, 50(2), 283-291.

Soares, R.N., Santos, R.O., \& Silva, B.M.S. (2019). Morphological aspects and anatomy of the fruit, seeds and seedlings of Pentaclethra macroloba (willd.) Kuntze (Fabaceae). Journal of Seed Science, 41(4), 452-460.

ter Steege, H., Pitman, N.C.A., Sabatier, D., Baraloto, C., Salomão, R.P., Guevara, J.E., ... Silman, M.R. (2013). Hyperdominance in the Amazonian tree flora. Science, 342(6156), 325-334.

Tropicos. (2019). Missouri Botanical Garden. Retrieved 11 February 2019, from http://www.tropicos.org

Vilhena, J.E.S., Silva, R.B.L., \& Freitas, J.L. (2018). Climatologia do Amapá: quase um século de história. Rio de Janeiro, Brasil: Gramma.

Walter, C.A., \& Bien, A. (1989). Aerial root nodules in the tropical legume, Pentaclethra macroloba. Oecologia, 80(1), 27-31.

Wiens, J.J. (2011). The niche, biogeography and species interactions. Philosophical Transactions of the Royal Society B: Biological Sciences, 366(1576), 2336-2350.

Williamson, G.B., \& Costa, F. (2000). Dispersal of Amazonian Tress: hydrocory in Pentaclethra macroloba. Biotropica, 32(3), 548-552. 